\title{
LETRAMENTO CRÍTICO E INTERCULTURALIDADE NAS AULAS DE LÍNGUA INGLESA NA EDUCAÇÃO DE JOVENS E ADULTOS
}

\author{
Critical literacy and intercultural education in English classes for Young Learners \\ and Adults
}

\section{Katia Bruginski MULIK, UTFPR ${ }^{1}$}

RESUMO: O objetivo deste texto é relatar uma proposta de trabalho realizada com os alunos do ensino médio da Educação de Jovens e Adultos acerca da temática alimentação. As atividades desenvolvidas foram baseadas em princípios do letramento crítico e dos estudos sobre interculturalidade. $\mathrm{O}$ trabalho foi de suma importância para $\mathrm{O}$ desenvolvimento da criticidade e para a reflexão sobre as relações entre cultura e alimentação.

PALAVRAS-CHAVE: ensino de língua inglesa; letramento crítico; interculturalidade.

ABSTRACT: The aim of this text is to report a didactic sequence about food and eating habits applied in an English class at the secondary level of the Education for Young Learners and Adults modality. The activities emphasized the critical literacy and intercultural aspects. The work was very important for the development of criticality and reflection on the relationship between culture and eating.

KEY-WORDS: English teaching; critical literacy; intercultural education.

\section{INTRODUÇÃO}

Ao se pensar sobre ensino de uma língua estrangeira na escola é imprescindível levar em consideração que dentro deste contexto o currículo necessita voltar-se para a formação do educando para a cidadania visando superar visões utilitaristas que buscam apenas atingir fins comunicativos e que ao mesmo tempo "restringem as possibilidades de sua aprendizagem como experiência de identificação social e cultural (DCE - LEM 2008, p. 53)". Nesse sentido, é necessário incorporar novas práticas que possibilitem o debate de temas que auxiliem na (re) construção da criticidade do educando fazendo-o entrar em contato com aspectos da vida social e cultural.

Neste relato de experiência objetivo apresentar uma sequência didática elaborada sob a ótica do letramento crítico e da abordagem intercultural de ensino de línguas. $\mathrm{O}$

\footnotetext{
${ }^{1}$ Mestranda em Estudos Linguísticos na Universidade Federal do Paraná.
} 
primeiro, de acordo com Andreotti (2008, p. 42) "ajuda os alunos a analisarem as relações entre língua, poder, práticas sociais, identidades e desigualdades”. Assim, os alunos podem "imaginar-se de outro modo; para estar envolvido eticamente com a diferença; e para entender as implicações potenciais de seus pensamentos e ações (idem) $)^{2,}$. Já a segunda, “além de reconhecer a língua como meio de comunicação, traz conjuntamente para o ensino de LE a reflexão sobre suas funções sociais, como a maneira pela qual a linguagem é usada - escrita e oralmente - para negociar sua posição em grupos diferentes (MOROSOV e MARTINEZ, 2008, p. 64)".

O ensino sob a ótica do letramento crítico propõe a "problematização dos textos como forma de refletir sobre os sentidos construídos e de (re) conhecer e (re) elaborar as construções discursivas de si e dos outros no processo de leitura (EDMUNDO, 2010, p. 34-35)". A leitura é entendida como um "processo interpretativo e a língua, nesse segmento, é concebida como discurso (idem)”. Essa visão de língua se enquadra numa perspectiva bakhtiniana "o emprego da língua efetua-se em forma de enunciados (...) cada campo de utilização da língua elabora seus tipos relativamente estáveis de enunciados, os quais denominamos gêneros do discurso (BAKHTIN, 2003, p. 262-3)". A intenção discursiva, bem como a sua individualidade e subjetividade é aplicada a adaptada ao gênero escolhido, constituindo-se e desenvolvendo-se a partir dessa forma. Nesse sentido, ao conceber a língua como discurso "permite-se aos sujeitos perceberemse como integrantes da sociedade e participantes ativos do mundo (DCE - LEM, 2008, p. 57)".

Segundo as DCE - LEM (2008, p. 56) "as sociedades contemporâneas não sobrevivem de modo isolado; relacionam-se, atravessam fronteiras geopolíticas e culturais, comunicam-se e buscam entender-se mutuamente". Ainda nas DCE - LEM (2008, p.56) argumenta-se que o ensino de uma LE (língua estrangeira) "deve considerar as relações que podem ser estabelecidas entre a língua estudada e a inclusão social, objetivando o desenvolvimento da consciência do papel das línguas na sociedade e o reconhecimento da diversidade cultural”. Paraná e Almeida (2010) advogam que o trabalho com a interculturalidade faz com que o aluno seja "incentivado a desenvolver uma análise mais profunda e uma maior conscientização a respeito da própria cultura,

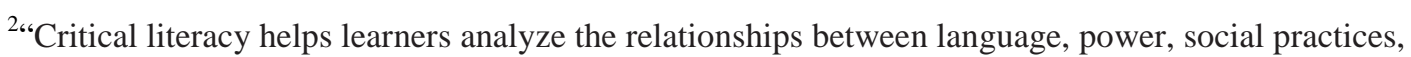
identities and inequalities; to imagine 'otherwise'; to engage ethically with difference; and to understand the potential implications of their thoughts and actions".
} 
colocando-se em prática a ideia de que é possível tornar familiar o que é pouco conhecido".

As questões apresentadas acima nortearam meu trabalho que consistiu no desenvolvimento de uma sequência didática para a disciplina de língua inglesa do ensino médio da rede pública estadual na Educação de Jovens e Adultos (doravante EJA) sobre o tema alimentação. Para isso, procurei elaborar atividades que integravam o ensino de vocabulário específico, leitura e discussão sobre gêneros textuais relacionados, produção de cartazes e apresentações orais.

\section{O TRABALHO COM TEMAS E O PERFIL DOS ALUNOS DA EJA}

A sala de inglês da EJA era composta por uma diversidade muito grande em termos de idade, condição social, interesse e escolarização. Além disso, percebi nos discursos de vários alunos que, para eles o inglês não constituía uma disciplina relevante para o currículo, ou seja, eles estavam carregados de crenças negativas sobre o ensino e isso acabava deixando-os desmotivados. Lidar com essa diversidade e desmotivação acaba, às vezes, sendo uma tarefa difícil se não houver planejamento e engajamento por parte do docente na elaboração de suas aulas. Outro fator que por vezes dificulta o trabalho é o fato de não haver Diretrizes Curriculares para a EJA específicas para cada disciplina. A orientação que se tem é seguir o mesmo esquema proposto para as séries do ensino regular. Embora as DCE tratem com igualdade os alunos do ensino regular e os da EJA, são notórias as distinções de perfil desses grupos.

O trabalho a partir de temas foi uma estratégia adotada a fim de atender as necessidades dos alunos. Era preciso organizar os conteúdos para que os alunos percebessem a proximidade que o inglês pode assumir com o próprio cotidiano deles visando despertar o interesse pela disciplina. Assim, entrei em comum acordo com os alunos e percebi que essa forma de trabalho ajudava na minha organização e planejamento das aulas e dos conteúdos e, ao mesmo tempo, atendia às expectativas dos alunos, uma vez que, busquei, na medida do possível, aderir aos temas sugeridos por eles estando o tema alimentação entre os sugeridos pela turma.

\section{Sequência didática}


Para iniciar o trabalho optei por realizar algumas atividades que pudessem introduzir o vocabulário sobre alimentação. Primeiramente, propus aos alunos a leitura de uma história em quadrinhos da Magali de Maurício de Souza, intitulada Meals. Nessa história, a personagem, ao retornar da sua aula de inglês, conversa com sua mãe em português, mas utiliza algumas das palavras que aprendeu na aula: "Quando que vai sair o breakfast?”. No decorrer da história, Magali fala o nome de vários alimentos e das refeições em inglês.

Após a leitura dessa HQ solicitei que os alunos identificassem os alimentos e as bebidas mencionados pela personagem agrupando-os de acordo com sua respectiva refeição (breakfast, lunch, snack, dinner e supper). Em seguida, solicitei que fizessem a própria lista das coisas que comumente comem nessas refeições. Discutimos também se eles fazem todas as refeições. Esse momento foi interessante, pois, como o perfil dos alunos da EJA era diferenciado, ou seja, são alunos que geralmente trabalham que cuidam dos filhos e da casa, foi uma oportunidade para que falassem sobre a própria realidade e mostrassem como a rotina pode influenciar na alimentação.

Com o intuito de dar continuidade às atividades das aulas anteriores propus um warm-up que consistia em um bingo sobre foods and drinks. Em seguida, apresentei o gênero tabela nutricional - Nutrition Facts. Cada aluno recebeu um texto, então solicitei que identificassem o gênero, questionando sobre o local de circulação, qual a sua função e conteúdo. Essa forma de trabalho pautou-se nas orientações das DCE - LEM (2008, p. 63) que enfatizam que “disponibilizar textos aos alunos não é o bastante. É necessário provocar uma reflexão maior sobre o uso de cada um deles e considerar o contexto de uso de seus interlocutores".

Posterior à exploração das características principais do gênero realizei algumas atividades mais específicas com questões sobre o vocabulário: calories, cholesterol, sodium, potassium carbohydrate, protein, calcium e vitamin. Durante a realização das atividades percebi que os alunos apresentaram muitas dúvidas sobre o significado dessas palavras, em relação ao que é benéfico ou ruim para a saúde principalmente. Então propus que, na aula seguinte eles trouxessem uma pesquisa sobre esse vocabulário para que pudéssemos discutir em sala.

A partir da pesquisa montamos uma tabela no quadro negro explicando o significado dos termos. Essa atividade teve uma repercussão muito boa, uma vez que a partir da língua inglesa eles puderam transferir esse conhecimento para a língua materna 
conseguindo compreender melhor o conteúdo do gênero tabela nutricional. Isso ilustra o que está presente nas DCE - LEM (2008, p. 60) “consequentemente é na língua, e não por meio dela que se percebe e entende a realidade e, por efeito, a percepção do mundo está intimamente ligada ao conhecimento das línguas". Além disso, discutimos sobre o tipo de conhecimento veiculado em tais tabelas levando em consideração que seu conteúdo é pautado na experiência científica, ou seja, as tabelas nutricionais são elaboradas a partir de experimentos laboratoriais e buscam expressar valores exatos e reais.

Após a realização dessa sequência de atividades percebi que os alunos já haviam adquirido um bom vocabulário, o que era necessário para que discutíssemos sobre questões culturais acerca do tema alimentação. Diante da questão da interculturalidade concordo com Mendes (2007, p. 119) que advoga que é preciso pensar a cultura dentro do ensino de línguas não como um "conjunto de conteúdos informativos e exóticos sobre determinado país, região, comunidade ou grupo específico, e, consequentemente, a língua como conjunto de aspectos estruturais que tem existência independente de toda a rede social que a envolve".

A primeira atividade proposta nessa fase foi uma discussão sobre estereótipos culturais relacionados à alimentação. Apresentei alguns flashcards com figuras que ilustravam alimentos como hambúrguer, pizza e feijoada e solicitei que eles relacionassem a que país o alimento ou a bebida pertenciam. Nesse momento discutimos sobre a questão da cultura e da alimentação refletindo sobre os possíveis estereótipos construídos. Os alunos mostraram-se entusiasmados com a discussão e questionaram sobre a forma como são feitas essas convenções em que determinado alimento seja típico de um país ou região, perguntando, coisas do tipo: "Professora, mas quem disse que a feijoada tem que ser o prato típico do Brasil?”, "Qual critério é utilizado para se estabelecer isso, já que nem todos os brasileiros comem ou gostam de feijoada?".

Sobre a importância de se trabalhar com a desmistificação de estereótipos, Bastos (2010, p. 32) propõem que "o ensino de línguas estrangeiras deve enfatizar que os estereótipos atribuídos a cada povo, inclusive o nativo, não são absolutos, ou seja, nenhum povo é desse ou daquele jeito". Diante disso, é importante considerar o ser humano como um ser complexo que apresenta variações de comportamento, de valores e crenças que podem ser modificadas dentro do processo histórico e cultural em que 
todos estão vivendo. Bastos ainda comenta que para que essa possibilidade de mobilidade e transformação possa se fortalecer "é fundamental que se questionem estereótipos que se tornaram verdades absolutas (...) através principalmente do ensino de línguas (BASTOS, 2010, p. 32)".

Esse debate introdutório mostrou a relevância do tema para os alunos contribuindo para a construção da competência cultural nas aulas de língua estrangeira que é definida por Gimenez (2008, p. 4):

\begin{abstract}
A competência cultural é entendida como o conhecimento sobre o que um determinado grupo cultural e entendimento dos valores culturais sobre determinadas formas de agir ou sobre certas crenças. Ao invés de só olhar o outro, o aprendiz se olha também, mas permanece com a ideia de que para comunicar-se adequadamente na língua estrangeira, deve olhar o mundo como o estrangeiro.
\end{abstract}

Dando sequência ao trabalho realizei com os alunos uma atividade sugerida por Corbett (2010) no livro Intercultural Language Activities. A atividade National dishes: cultural associations consiste em preencher uma tabela com o nome do prato, a que país pertence, que tipo de refeição é, o tipo de acompanhamento que se serve junto ao prato, a origem do prato e o que as pessoas fazem após ter saboreá-lo. A realização dessa atividade teve os mesmos objetivos descritos por Corbett (2010) que era fazer com que os alunos identificassem o prato associando-o com a cultura pertencente. Além disso, fazer com que os alunos pesquisassem sobre comidas, nacionalidades e culturas refletindo sobre tais aspectos e repensando sobre a própria cultura.

Dando continuidade ao trabalho optei por explorar mais a fundo sobre a questão da interculturalidade que foi despertada através dos debates e das outras atividades. Assim, solicitei que os alunos fizessem uma pesquisa e trouxessem uma receita de um prato típico de um país de sua preferência, bem como a origem do prato e o que justificava ele ser típico de um determinado país. Os alunos optaram por trabalhar com o Japão, a Itália e a Alemanha. Com a pesquisa realizada os alunos se reuniram em grupos para organizar os materiais. Discutimos sobre o que cada grupo trouxe e exploramos o gênero receita de forma coletiva. Os materiais foram organizados em forma de cartazes e expostos e um mural da escola.

Nas aulas seguintes cada grupo fez a apresentação oral da receita e dos demais aspectos culturais relacionados com o prato e o país escolhido. Como sugestão dos próprios alunos, o grupo que apresentava deveria trazer o prato típico para compartilhar 
com os colegas em sala. Então, durante três semanas, os alunos puderam saborear yakisoba, pizza e torta alemã. Certamente essas apresentações contribuíram para que os alunos conseguissem perceber que o encontro entre culturas é um processo dialógico, por vezes complexo, porém essencial dentro da aprendizagem de línguas estrangeiras.

Como considerações finais deste relato penso que é importante registrar as boas impressões que tive e que percebi durante a realização das atividades. Os alunos mostraram-se satisfeitos com o trabalho realizado, pois conseguiram perceber que as aulas de inglês podem ser interessantes e que pode tratar de temas significativos e se sentiram mais motivados.

Essa sequência didática foi desenvolvida durante cerca de doze aulas. A elaboração e o planejamento demandaram tempo, no entanto os resultados obtidos foram riquíssimos. Alguns desafios foram superados como, por exemplo, a questão dos debates que não eram regularmente praticados nas aulas de inglês.

O desafio de fazer apresentações orais também foi superado, pois eles conseguiram realizar a atividade com êxito. No entanto, quando questionei sobre o aproveitamento da proposta de trabalho uma das coisas que mais me chamou a atenção foi o fato de que alguns alunos falarem que isso tudo oportunizou que eles discutissem sobre coisas diferentes e experimentassem alimentos que ainda não haviam comido proporcionando a integração da turma. Esse envolvimento da sala na realização e participação da atividade ilustra como aspectos sociais e culturais podem ser incorporados na sala de língua estrangeira, pois a cultura, segundo as DCE da EJA (2006, p. 32) "compreende a forma de produção de vida material e imaterial que compõe um sistema de significações envolvido em todas as formas de atividade social".

Acredito que o que relatei nesse texto é um exemplo de troca de conhecimento e de experiências nas aulas de língua estrangeira que pode e deve ser promovido constantemente por outros professores. Diante do que apresentei concordo com Souza (2011, p.1) ao afirmar que "preparar os aprendizes para confrontos com diferenças de toda espécie se torna um objetivo pedagógico atual e premente, que pode ser alcançado através do letramento crítico", trazendo para sala de aula temas que estejam presentes na vida do aluno, provocando novos questionamentos ou até mesmo resgatando velhos, visando a formação de alunos capazes de recriar e transformar o mundo que os cerca.

\section{REFERÊNCIAS}


ANDREOTTI, Vanessa. Innovative methodologies in global citizenship education: the OSDE initiative. In: Gimenez, T.; Sheehan, S.. (Org.). Global citizenship in the English language classroom. 1 ed. : , 2008, v. 1, p. 40-47.

BASTOS, Herzila Maria de Lima. Identidade cultural e o ensino de línguas estrangeiras no Brasil. In: PAIVA, Vera Lucia Menezes de Oliveira e. Ensino de língua inglesa: reflexões e experiências (Org). $4^{\mathrm{a}}$ ed. Campinas, SP: Pontes Editores, 2010.

BAKHTIN, Mikhail. Estética da criação verbal. $4^{\text {a }}$ ed. São Paulo: Martins Fontes, 2003.

CORBETT, John. Intercultural Language Activities. Cambridge University Press: United Kingdom, 2010.

EDMUNDO, Eliana Santiago. $O$ ensino de inglês na escola pública sob a perspectiva do letramento crítico. Dissertação de Mestrado. Programa de Pós-graduação em Letras: Estudos Linguísticos, 2010. Disponível em:

http://dspace.c3sl.ufpr.br/dspace/bitstream/handle/1884/24961/DISSERTACAO\%20EL IANA\%20SANTIAGO.pdf?sequence=1 Acesso em: 10 de outubro de 2011.

GIMENEZ, Telma. "Eles comem cornflakes, nós comemos pão com manteiga": espaços para reflexão sobre cultura na aula de língua estrangeira. Disponível em: http://www.utp.br/nepri/halu/tesig/cornflakes_com_manteiga.htm Acesso em: $10 \mathrm{de}$ julho de 2011.

MENDES, Edleise. A perspectiva intercultural no ensino de línguas: relação entreculturas. In: ALVAREZ, Maria Luisa Ortiz; SILVA, Kleber Aparecido da.(Orgs). Linguística Aplicada: múltiplos olhares. Brasília: DF: UnB; Campinas: SP: Pontes editores, 2007.

MOROSOV, Ivete; MARTINEZ, Juliana Zeggio. A didática do ensino e a avaliação da aprendizagem em língua estrangeira. Curitiba: IBPEX, 2008.

PARANÁ, Jeanne Marie Féder; ALMEIDA, Mariza Riva de. Seminários sobre interculturalidade - em busca do resgate da cultura no ensino de línguas estrangeira. Disponível em: http://people.ufpr.br/ marizalmeida/celem05/\#textos Acesso em: $22 \mathrm{de}$ junho de 2010.

PARANÁ. Secretaria de Estado da Educação. Diretrizes Curriculares da Educação de Jovens e Adultos - versão preliminar. Curitiba, PR: SEED, 2006.

Diretrizes Curriculares da Educação Básica: Língua Estrangeira Moderna. Curitiba, PR: SEED, 2008.

SOUZA, Lynn Mario T. Menezes de. Por uma redefinição de Letramento Crítico: conflito e produção de significação. Disponível em:

http://uspbr.academia.edu/LynnMarioMenezesdeSouza/Papers/599422/Para_um_redefi 
nicao_de letramento_critico_conflito_e_producao_de_significacao Acesso em 10 de outubro de 2011. 